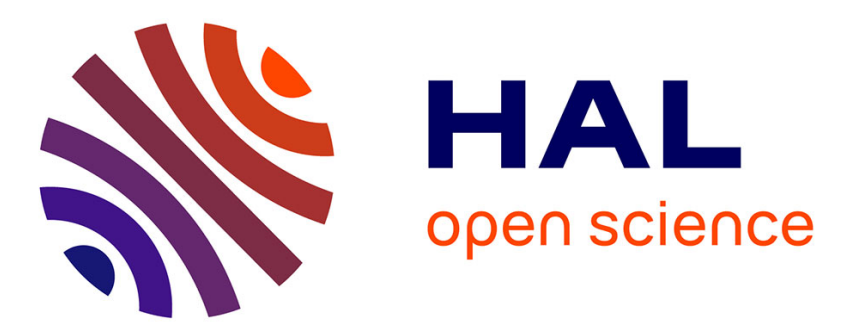

\title{
Binuclear Schiff-base zinc(II) complexes: Synthesis, crystal structures and reactivity toward ring opening polymerization of rac-lactide
}

D.M. González, J. Cisterna, I. Brito, T. Roisnel, J.-R. Hamon, C. Manzur

\section{- To cite this version:}

D.M. González, J. Cisterna, I. Brito, T. Roisnel, J.-R. Hamon, et al.. Binuclear Schiff-base zinc(II) complexes: Synthesis, crystal structures and reactivity toward ring opening polymerization of raclactide. Polyhedron, 2019, 162, pp.91-99. 10.1016/j.poly.2019.01.043 . hal-02051168

HAL Id: hal-02051168

https://hal-univ-rennes1.archives-ouvertes.fr/hal-02051168

Submitted on 13 Mar 2019

HAL is a multi-disciplinary open access archive for the deposit and dissemination of scientific research documents, whether they are published or not. The documents may come from teaching and research institutions in France or abroad, or from public or private research centers.
L'archive ouverte pluridisciplinaire HAL, est destinée au dépôt et à la diffusion de documents scientifiques de niveau recherche, publiés ou non, émanant des établissements d'enseignement et de recherche français ou étrangers, des laboratoires publics ou privés. 


\title{
Binuclear Schiff-Base Zinc(II) complexes: Synthesis, crystal structures and reactivity toward ring opening polymerization of rac-Lactide
}

\author{
Darío M. González *a, ${ }^{*}$ Jonathan Cisterna ${ }^{\mathrm{b}}$, Iván Brito ${ }^{\mathrm{b}}$, Thierry Roisnel ${ }^{\mathrm{c}}$, Jean-René Hamon ${ }^{\mathrm{c}}$, \\ Carolina Manzur ${ }^{\text {a }}$ \\ a Instituto de Química, Pontificia Universidad Católica de Valparaíso, Campus Curauma, Avenida Universidad 330, \\ Valparaíso, Chile \\ ${ }^{b}$ Departamento de Química, Facultad de Ciencias Básicas, Universidad de Antofagasta, Avda. Universidad de \\ Antofagasta 02800, Campus Coloso, Antofagasta, Chile \\ ${ }^{c}$ Univ Rennes, CNRS, ISCR (Institut des Sciences Chimiques de Rennes) - UMR 6226, F-35000 Rennes, France
}

This paper is dedicated to Prof. David Carrillo (PUCV), a highly esteemed mentor, colleague, and friend at the occasion of his $80^{\text {th }}$ birthday.

* Corresponding author.

e-mail address: dario.gonzalez@pucv.cl (D.M. González)

\begin{abstract}
Upon crystallization from DMF/diethyl ether or $\mathrm{CH}_{2} \mathrm{Cl}_{2} /$ pyridine of tetracoordinated $\mathrm{Zn}$ (II) complexes containing either 4-fluorophenyl or 4-anisyl substituted O,N,O-tridentate Schiff base ligands and pyridine as auxiliary ligand, three new doubly phenoxide-bridged dimeric $\mathrm{Zn}$ (II) complexes were isolated and their catalytic properties for the ring opening polymerization (ROP) of rac-lactide were explored. The single-crystal XRD analysis allowed to corroborate the molecular structures of the binuclear complexes, showing that the pentacoordinated $\mathrm{Zn}$ (II) metal ion adopts a slightly distorted square pyramidal geometry. The basal plane Is formed by the O,N,O-donor set of the tridentate Schiff base ligand and a phenoxo bridging oxygen, while a pyridine or a DMF molecule is located at the apex of the pyramid. The binuclear complexes were employed as catalysts in the ROP of rac-lactide for polylactide (PLA) synthesis. Polymerization conditions such as reaction time, catalyst concentration and use of benzyl alcohol as cocatalyst were studied, as well as their influence on the conversion rate, average molecular weight and polydispersity of the obtained PLA. The catalyst substituted with fluorine was more reactive, but with a lower control on the molecular weight compared to the methoxy-substituted catalyst. On the other hand, the presence of pyridine as an auxiliary ligand generates an improvement in the polydispersity of PLA.
\end{abstract}

Keywords: Binuclear Zinc complexes; Schiff-Base ligands: X-ray diffraction; Ring opening polymerization; Polylactide 


\section{Introduction}

The development of biodegradable polymers is currently a subject of great scientific interest, as it points to the possibility of replacing some applications of traditional petrochemical plastic materials. In this context, in the last decade, polylactide (PLA) is one of the most promising and its research has grown significantly since in addition to its biodegradable characteristics, it is also biocompatible and of bio-sourced origin [1-5]. Another important characteristic of PLA is that it can achieve physical properties and mechanical behaviors similar to that of polyolefins when synthesized by ring-opening polymerization (ROP) from a lactide (LA) monomer unit using a suitable catalytic system [6-9]. The catalysts used for PLA synthesis have evolved over time: the first catalysts were metals like tin alkoxides [9-11], and have since reached increasingly complex species like some organometallic compounds, and, more recently, coordination complexes [12]. There are currently a wide variety of metal complexes that have been studied as ROP catalysts, with general success in the use of $\mathrm{Al}$ as a metal center [13-19], some alkaline [20-22]and alkaline earth metals [23-25], and also some transition metals like Ti or Zr [26]. However, Zinc-based complexes are among the most outstanding, mainly because of good polymerization control via ROP, which translates into good catalytic activity, high molecular weight, low polydispersity, and even stereochemical control of synthesized PLA [27-33].In addition, Zn has low toxicity compared to other metals.

With respect to the design of a coordination complex for ROP catalysis, the choice of central metal atom is undoubtedly a highly determining factor; that said, ligands also have an important role in the catalytic behavior of the complex, influencing reactivity and even some structural characteristics of the synthesized polymers [23,34]. Furthermore, the development of numerous synthesis routes has allowed a wide variety of coordination compounds to exist today, e.g., ligands with different structures, symmetries, chelating heteroatoms, and substituent groups. Because of this, the range of complexes used in ROP catalysis has grown enormously, though without consensus on the real influence of metal complex structure in ROP. Rather, it is generally only possible to approximate catalyst functions as a set of structural variables, taken from different polymerization experimental conditions, optimized for the use of each catalyst.

To this end, this paper proposes the use of Schiff-base ligands derived from $\beta$-diketones. The latter are characterized as versatile molecules and very good coordinators, with the ability to stabilize a wide variety of metals in different oxidation states. In addition, their simple synthesis routes are of good performance and so are easily functionalized [35-39]. Considering the good results found with Zinc in ROP reactions, the objective is to study Schiff-base ligands and their respective complexes 
with different substituent groups, such as fluorine and methoxyl, and to subsequently evaluate their catalytic activity in rac-LA polymerization in terms of catalytic performance, molecular weights and polydispersities in obtained PLA.

\section{Experimental}

\subsection{General experimental methods}

Reactions were performed under dry dinitrogen atmosphere using standard Schlenk lines. Solvents were dried and distilled according to standard procedures [40]. 1-(4-methoxyphenyl)-1,3butanedione [41], 1-(4-fluorophenyl)-1,3-butanedione [42], and the Schiff base proligand 4-MeO$\mathbf{C}_{6} \mathbf{H}_{4}-\mathbf{C}(\mathbf{O}) \mathbf{C H}=\mathbf{C}\left(\mathbf{C H}_{3}\right) \mathbf{N}(\mathbf{H})-\mathbf{C}_{6} \mathbf{H}_{4}-\mathbf{2}-\mathbf{O H}$ (1) [38], were synthesized according to literature procedures. All other chemicals were purchased from commercial sources and used without further purification. ${ }^{1} \mathrm{H}$ NMR spectra were recorded at $298 \mathrm{~K}$ with a Bruker 300 FT-NMR spectrometer. Chemical shifts $(\delta)$ are reported in parts per million $(\mathrm{ppm})$ and referenced to the residual deuterated solvent peaks $\left(\mathrm{CDCl}_{3}: \delta=7.26 \mathrm{ppm} ;\left(\mathrm{CD}_{3}\right)_{2} \mathrm{SO}: \delta=2.50 \mathrm{ppm}\right)$. Coupling constants $(J)$ are reported in Hertz $(\mathrm{Hz})$, and integrations are reported as number of protons. High resolution electrospray ionization mass spectra (ESI-MS) were obtained at the Centre Regional de Mesures Physiques de l'Ouest (CRMPO, Université de Rennes 1, France) with a Thermo Fisher Scientific Q-Exactive mass spectrometer. Elemental analyses were conducted on a Thermo-Finnigan Flash EA 1112 CHNS/O analyzer of the CRMPO Microanalytical Service. Melting points were measured in evacuated capillaries on a Kofler Bristoline melting point apparatus and were not corrected. GPC measurements were performed on a Shimadzu DGU-20A3R with a Shimadzu RID-10A RI detector and a combination two-column Shimadzu Shim-pack GPC-800DP and GPC-80MD.The molecular weight and polydispersity index were calculated according to polystyrene standards.

\subsection{Synthesis of Schiff base proligand 2 and complexes}

\subsubsection{Synthesis of $\mathrm{O}, \mathrm{N}, \mathrm{O}$-tridentate Schiff base proligand 2: $\left(4-\mathrm{F}-\mathrm{C}_{6} \mathrm{H}_{4}\right)-\mathrm{C}(\mathrm{O}) \mathrm{CH}=\mathrm{C}\left(\mathrm{CH}_{3}\right) \mathrm{N}(\mathrm{H})-\mathrm{C}_{6} \mathrm{H}_{4}-2-\mathrm{OH}$}

A three necked round bottom flask equipped with a Dean-Stark apparatus was loaded with a magnetic stir bar, $1000 \mathrm{mg}$ (5,6 mmol) of 1-(4-fluorophenyl)-butane-1,3-dione, $672 \mathrm{mg}$ (6.2 $\mathrm{mmol}$ ) of 2-aminophenol, and $50 \mathrm{~mL}$ of toluene. The reaction mixture was refluxed for $5 \mathrm{~h}$. After cooling to room temperature, $10 \mathrm{~mL}$ of diethyl ether were added and the solution was stored at $-30{ }^{\circ} \mathrm{C}$ causing the precipitation of microcrystalline yellow solid. This material was 
collected by filtration, washed with $3 \times 2 \mathrm{~mL}$ portion of diethyl ether/pentane mixture (1:1), and dried under vacuum, providing $1338 \mathrm{mg}$ (86\% yield). M.p. $118-120^{\circ} \mathrm{C} .{ }^{1} \mathrm{H}$ NMR $(300 \mathrm{MHz}$, $\mathrm{CDCl}_{3}$ ): 1.77 (s, $3 \mathrm{H}, \mathrm{CH}_{3}$ ), 5.70 (s, $\left.1 \mathrm{H}, \mathrm{CH}=\mathrm{C}\right), 6.89$ (td, J=7.5 Hz, J=1.4 Hz, $1 \mathrm{H}, \mathrm{C}_{6} \mathrm{H}_{4}-2$ ), $7.05\left(\mathrm{td}, \mathrm{J}=8.0 \mathrm{~Hz}, \mathrm{~J}=1.2 \mathrm{~Hz}, 2 \mathrm{H}, \mathrm{F}_{-} \mathrm{C}_{6} \mathrm{H}_{4}\right), 7.13\left(\mathrm{~m}, 2 \mathrm{H}, \mathrm{C}_{6} \mathrm{H}_{4}-2\right), 7.21\left(\mathrm{~m}, 1 \mathrm{H}, \mathrm{C}_{6} \mathrm{H}_{4}-2\right), 7.90$ $\left(\mathrm{m}, 2 \mathrm{H}, \mathrm{F}-\mathrm{C}_{6} \mathrm{H}_{4}\right)$ and $12.35(\mathrm{~s}, 1 \mathrm{H}, \mathrm{NH})$.

\subsubsection{Synthesis of mononuclear complex 3 and 4: $\left[\left\{4-\mathrm{MeO}-\mathrm{C}_{6} \mathrm{H}_{4}-\mathrm{C}(\mathrm{O}) \mathrm{CH}=\mathrm{C}\left(\mathrm{CH}_{3}\right) \mathrm{N}-\mathrm{C}_{6} \mathrm{H}_{4}-2-\mathrm{O}\right\} \mathrm{Zn}^{\mathrm{II}}\left\{\mathrm{NC}_{5} \mathrm{H}_{5}\right\}\right]$ (3) and $\left[\left\{4-\mathrm{F}-\mathrm{C}_{6} \mathrm{H}_{4}-\right.\right.$ $\left.\left.\mathrm{C}(\mathrm{O}) \mathrm{CH}=\mathrm{C}\left(\mathrm{CH}_{3}\right) \mathrm{N}-\mathrm{C}_{6} \mathrm{H}_{4}-2-\mathrm{O}\right\} \mathrm{Zn}^{\mathrm{II}}\left\{\mathrm{NC}_{5} \mathrm{H}_{5}\right\}\right]$ (4)}

A Schlenk tube with a magnetic stir bar was loaded with Schiff base proligand 1 or 2 (0.71 mmol), potassium tert-butoxide $(2.1 \mathrm{mmol})$, and $3 \mathrm{~mL}$ of THF. The reaction mixture was stirred for $15 \mathrm{~min}$, with a dark red precipitate observed. Then, $2.1 \mathrm{mmol}$ of pyridine was slowly added, and after 15 min of stirring, a solution of $\mathrm{Zn}\left(\mathrm{NO}_{3}\right)_{2} \times 6 \mathrm{H}_{2} \mathrm{O}(1.1 \mathrm{mmol})$ in $1.5 \mathrm{~mL}$ of THF was added. The reaction mixture was vigorously stirred for $4 \mathrm{~h}$ at room temperature. The solvent was then evaporated to dryness under reduced pressure. The solid residue was dissolved in dichloromethane and filtered to remove excess salts. The solution was evaporated to dryness, yielding a solids sample of $\mathbf{3}$ or $\mathbf{4}$, respectively.

Compound 3: yellow solid; $200 \mathrm{mg}\left(66 \%\right.$ yield). $180^{\circ} \mathrm{C}$ (Dec.). Anal. Calcd for $\mathrm{C}_{22} \mathrm{H}_{20} \mathrm{~N}_{2} \mathrm{O}_{3} \mathrm{Zn}$ (425.79 $\left.\mathrm{g} \mathrm{mol}^{-1}\right): \mathrm{C}, 62.06 ; \mathrm{H}, 4.73 ; \mathrm{N}, 6.58$. Found: C, 60.95; H, 4.68; N, 6.18. ESI-MS (m/z) calcd for $\mathrm{C}_{22} \mathrm{H}_{20} \mathrm{~N}_{2} \mathrm{O}_{3}{ }^{64} \mathrm{Zn}$ : 424.07599, found: 424.0760 (0 ppm). ${ }^{1} \mathrm{H}$ NMR (300 MHz, DMSO- $\mathrm{d}_{6}$ ): 2.32 $\left(\mathrm{s}, 3 \mathrm{H}, \mathrm{CH}_{3}\right), 3.82\left(\mathrm{~s}, 3 \mathrm{H}, \mathrm{OCH}_{3}\right), 5.70(\mathrm{~s}, 1 \mathrm{H}, \mathrm{CH}=\mathrm{C}), 6.53\left(\mathrm{t}, \mathrm{J}=7.3 \mathrm{~Hz} 1 \mathrm{H}, \mathrm{C}_{6} \mathrm{H}_{4}-2\right), 6.86(\mathrm{t}, \mathrm{J}=$ $\left.7.3 \mathrm{~Hz}, 1 \mathrm{H}, \mathrm{C}_{6} \mathrm{H}_{4}-2\right), 7.01\left(\mathrm{~d}, \mathrm{~J}=8.7 \mathrm{~Hz}, 2 \mathrm{H}, 4-\mathrm{C}_{6} \mathrm{H}_{4} \mathrm{O}\right), 7.07$ (d, J=8.0 Hz, $\left.1 \mathrm{H}, \mathrm{C}_{6} \mathrm{H}_{4}-2\right), 7.18$ (d, $\left.\mathrm{J}=7.7 \mathrm{~Hz} 1 \mathrm{H}, \mathrm{C}_{6} \mathrm{H}_{4}-2\right), 7.40\left(\mathrm{~m}, 2 \mathrm{H}, \mathrm{C}_{5} \mathrm{H}_{5} \mathrm{~N}\right), 7.80\left(\mathrm{~m}, 1 \mathrm{H}, \mathrm{C}_{5} \mathrm{H}_{5} \mathrm{~N}\right), 7.93\left(\mathrm{~d}, \mathrm{~J}=8.7 \mathrm{~Hz}, 2 \mathrm{H}, \mathrm{C}_{6} \mathrm{H}_{4}-\right.$ $2)$, and $8.58\left(\mathrm{~m}, 2 \mathrm{H}, \mathrm{C}_{5} \mathrm{H}_{5} \mathrm{~N}\right)$.

Compound 4: orange solid; $153 \mathrm{mg}$ (52\% yield). $200^{\circ} \mathrm{C}$ (Dec.). Anal. Calcd for $\mathrm{C}_{21} \mathrm{H}_{17} \mathrm{FN}_{2} \mathrm{O}_{2} \mathrm{Zn}$ $\left(413.76 \mathrm{~g} \mathrm{~mol}^{-1}\right): \mathrm{C}, 60.96 ; \mathrm{H}, 4.14 ; \mathrm{N}, 6.77$. Found: C, 59.90; H, 4.11; N, 6.55. ESI-MS $(\mathrm{m} / z)$ calcd for $\mathrm{C}_{21} \mathrm{H}_{17} \mathrm{~N}_{2} \mathrm{O}_{2} \mathrm{~F}^{64} \mathrm{Zn}$ : 412.056, found: 412.0559 (0 ppm). ${ }^{1} \mathrm{H}$ NMR (300 MHz, DMSO-d $\left.)_{6}\right): 2.32(\mathrm{~s}, 3$ $\left.\mathrm{H}, \mathrm{CH}_{3}\right), 5.72(\mathrm{~s}, 1 \mathrm{H}, \mathrm{CH}=\mathrm{C}), 6.53\left(\mathrm{~m}, 1 \mathrm{H}, \mathrm{C}_{6} \mathrm{H}_{4}-2\right), 6.88\left(\mathrm{~m}, 1 \mathrm{H}, \mathrm{C}_{6} \mathrm{H}_{4}-2\right), 7.08\left(\mathrm{~m}, 1 \mathrm{H}, \mathrm{C}_{6} \mathrm{H}_{4-}\right.$ 2),7.16 (m, $\left.1 \mathrm{H}, \mathrm{C}_{6} \mathrm{H}_{4}-2\right) 7.27\left(\mathrm{~m}, 2 \mathrm{H},\left(4-\mathrm{C}_{6} \mathrm{H}_{4} \mathrm{~F}\right), 7.42\left(\mathrm{~m}, 2 \mathrm{H}, \mathrm{C}_{5} \mathrm{H}_{5} \mathrm{~N}\right), 7.82\left(\mathrm{~m}, 1 \mathrm{H}, \mathrm{C}_{5} \mathrm{H}_{5} \mathrm{~N}\right)\right.$, $8.00\left(\mathrm{~m}, 2 \mathrm{H}, 4-\mathrm{C}_{6} \mathrm{H}_{4} \mathrm{~F}\right), 8.57\left(\mathrm{~m}, 2 \mathrm{H}, \mathrm{C}_{5} \mathrm{H}_{5} \mathrm{~N}\right)$. 


\subsubsection{Binuclear complexes obtained by recrystallization: Compounds 5,6, and 7 .}

Complex 5 was obtained by slow evaporation of a saturated solution of compound 4 (100 $\mathrm{mg})$ in $\mathrm{CH}_{2} \mathrm{Cl}_{2} /$ pyridine (10:1) as orange monocrystals. This methodology requires a filtration procedure with celite to obtain an adequate and completely translucent solution, causing product losses and generating overall yields of $30 \%$. For complexes $\mathbf{6}$ and 7, $100 \mathrm{mg}$ of compounds $\mathbf{3}$ and 4, respectively, were dissolved in the minimum amount of DMF and subjected to slow vapor diffusion of diethyl ether for up to 7 days, yielding dark orange monocrystals of complexes 6 and 7 . The overall yield reached $35 \%$, through increasable up to $40 \%$ via recovery and concentration of the mother liquor and repeated recrystallization processes. All compounds were characterized via single-crystal XRD, corroborating their binuclear structures.

\subsection{X-ray crystal structure determination}

Some suitable crystals of compounds 5-7 were measured and their diffraction data were collected at 295(2) K on a Bruker D8 QUEST and D8 Venture diffractometer equipped with a bidimensional CMOS Photon100 detector, using graphite monochromated $\mathrm{Cu}-\mathrm{K} \alpha(\lambda=1.54178 \AA)$ and $\mathrm{Mo}-\mathrm{K} \alpha(\lambda=$ $0.71073 \AA$ A) radiation, respectively. The diffraction frames were integrated using the APEX3 package [43] and were corrected for absorptions with SADABS. The structures of $5-7$ were solved by intrinsic phasing [44] using the OLEX 2 program [45]. All the structures were then refined with full-matrix least-square methods based on $F^{2}$ (SHELXL-2014)[44]. For the three compounds, nonhydrogen atoms were refined with anisotropic displacement parameters. All hydrogen atoms were included in their calculated positions, assigned fixed isotropic thermal parameters and constrained to ride on their parent atoms. A summary of the details about crystal data, collection parameters and refinement are documented in Table 1, and additional crystallographic details are in the CIF files. ORTEP views were drawn using OLEX2 software [45].

Table 1. Crystal data parameters for compounds 5-7.

\begin{tabular}{|c|c|c|c|}
\hline Compound & 5 & 6 & 7 \\
\hline Empirical Formula & $\mathrm{C}_{42} \mathrm{H}_{34} \mathrm{~F}_{2} \mathrm{~N}_{4} \mathrm{O}_{4} \mathrm{Zn}_{2}$ & $\mathrm{C}_{40} \mathrm{H}_{44} \mathrm{~N}_{4} \mathrm{O}_{8} \mathrm{Zn}_{2}$ & $\mathrm{C}_{38} \mathrm{H}_{38} \mathrm{~F}_{2} \mathrm{~N}_{4} \mathrm{O}_{6} \mathrm{Zn}_{2}$ \\
\hline Formula mass, $\mathrm{g} \mathrm{mol}^{-1}$ & 827.47 & 839.53 & 815.46 \\
\hline Collection $\mathrm{T}, \mathrm{K}$ & $295(2)$ & $295(2)$ & $295(2)$ \\
\hline crystal system & Orthorhombic & Triclinic & Monoclinic \\
\hline space group & Pbca & $\mathrm{P} \overline{1}$ & $\mathrm{P} 2_{1} / \mathrm{c}$ \\
\hline$a(\AA)$ & $16.771(3)$ & $8.3006(3)$ & $11.2365(6)$ \\
\hline$b(\AA)$ & $9.8456(17)$ & $10.19115(4)$ & $8.3087(4)$ \\
\hline$c(\AA)$ & $22.075(4)$ & $11.3579(4)$ & $19.4733(10)$ \\
\hline$\alpha\left(^{\circ}\right)$ & 90 & $81.273(2)$ & 90 \\
\hline$\beta\left(^{\circ}\right)$ & 90 & $89.629(2)$ & $93.571(2)$ \\
\hline$\gamma\left({ }^{\circ}\right)$ & 90 & $70.055(2)$ & 90 \\
\hline$V\left(\AA^{3}\right)$ & $3645(10)$ & $954.68(6)$ & $1814.51(16)$ \\
\hline
\end{tabular}




\begin{tabular}{llll}
$Z$ & 4 & 1 & 2 \\
$\rho_{\text {calcd }}\left(\mathrm{gcm}^{-3}\right)$ & 1.508 & 1.460 & 1.493 \\
Crystal size $(\mathrm{mm})$ & $0.18 \times 0.17 \times 0.08$ & $0.23 \times 0.20 \times 0.16$ & $0.592 \times 0.371 \times$ \\
& & & 0.359 \\
$F(000)$ & 1696.0 & 436.0 & 840.0 \\
abs coeff $\left(\mathrm{mm}^{-1}\right)$ & 1.376 & 1.314 & 2.153 \\
$\theta$ range $\left({ }^{\circ}\right)$ & $6.382-56.662$ & $2.917-27.455$ & $9.1-130.52$ \\
range h,k,1 & $-22 / 22,-13 / 13,-29 / 29$ & $-8 / 10,-13 / 14$, & $-12 / 13,-9 / 9,-22 / 22$ \\
& & $14 / 13$ & \\
No. total refl. & 57447 & 13313 & 20669 \\
No. unique refl. & 4510 & 4218 & 3079 \\
Comp. $\theta_{\text {max }}(\%)$ & 99.5 & 96.5 & 99.1 \\
Max/min transmission & $0.781 / 0.896$ & $0.810 / 0.759$ & $0.441 / 0.462$ \\
Data/Restraints/Parameters & $4510 / 0 / 246$ & $4218 / 0 / 218$ & $3079 / 0 / 239$ \\
Final R[I>2 $\sigma(I)]$ & $\mathrm{R}_{1}=0.0439$, & $\mathrm{R}_{1}=0.0261$, & $\mathrm{R}_{1}=0.0387$, \\
& $\mathrm{wR}_{2}=0.0939$ & $\mathrm{wR}_{2}=0.0621$ & $\mathrm{wR}_{2}=0.1123$ \\
R indices (all data) & $\mathrm{R}_{1}=0.0652$, & $\mathrm{R}_{1}=0.0313$, & $\mathrm{R}_{1}=0.0417$, \\
& $\mathrm{wR}_{2}=0.1033$ & $\mathrm{wR}_{2}=0.0647$ & $\mathrm{wR}_{2}=0.1147$ \\
Goodness of fit / $\mathrm{F}^{2}$ & 1.171 & 1.035 & 1.055 \\
Largest diff. Peak/hole $\left(\mathrm{e} \AA^{-3}\right)$ & $0.550 /-0.400$ & $0.331 /-0.204$ & $0.830 /-0.500$ \\
\hline
\end{tabular}

\section{4.rac-Lactide polymerization}

In a typical experiment for polymerization in melt, a round bottom flask was charged with a stirring bar, $1.5 \mathrm{~g}(10.4 \mathrm{mmol})$ of rac-LA, $22 \mathrm{mg}(0.013 \mathrm{mmol}, 0.125 \% \mathrm{~mol})$ of catalyst 5 , and $55 \mathrm{mg}(0.5$ mmol) of benzylalcohol. The reaction mixture was melted at $130{ }^{\circ} \mathrm{C}$ with an oil bath and stirred for $4 \mathrm{~h}$. The flask was taken off, cooled to room temperature, and opened in air. An aliquot was analyzed by $1 \mathrm{H}$ NMR spectroscopy for determining the conversion. $0.5 \mathrm{~mL}$ of acidic methanol $(1.0$ $\mathrm{M}, \mathrm{HCl} / \mathrm{MeOH}$ solution) was added in the flask, and the polymer was precipitated with excess methanol. Then, the supernatant solution was removed with a pipet and the polymer was dried under vacuum to constant weight. The ratios of rac-lactide, catalyst, benzylalcohol, and reaction times employed for the various catalytic tests are given in section 3.3 (Table 3).

\section{Results and discussions}

\subsection{Synthesis of ligands and complexes}

The synthetic route to the known 1 [38] and new 2 ligand precursors corresponds to a Claisen condensation between the appropriate 4-substituted acetophenone and ethyl acetate leading to the formation of the corresponding betadiketone, and subsequent condensation with 2-aminophenol to generate the desired O,N,O tridentate Schiff base proligands (Scheme 1). This route provided both compounds in high yields, around 85\%. Subsequent synthesis of mononuclear complexes 3 and 4 consists in abstracting two acidic protons of the ligands with an excess of potassium tert-butoxide. 
Pyridine is then incorporated as an auxiliary ligand -in slight excess to stabilize tetracoordinated complexes- before incorporating the $\mathrm{Zn}(\mathrm{II})$ salt $\left(\mathrm{Zn}\left(\mathrm{NO}_{3}\right)_{2} \times 6 \mathrm{H}_{2} \mathrm{O}\right)$ (Sheme 1). The observed color changes indicated reaction progress: the yellow and orange colors of ligands $\mathbf{1}$ and $\mathbf{2}$, respectively, turned intense red upon reaction with $t$-BuOK, and finally the $\mathrm{Zn}$ (ii) complexes $\mathbf{3}$ and $\mathbf{4}$ shaded to a color very similar to that of their respective ligands. Complexes $\mathbf{3}$ and $\mathbf{4}$ are isolated as powdered solids in $66 \%$ and $52 \%$ yields, respectively. They are soluble in dimethylformamide (DMF), dimethylsulfoxide (DMSO) and pyridine but are poorly soluble in more common organic solyents such as dichloromethane, acetonitrile and acetone.

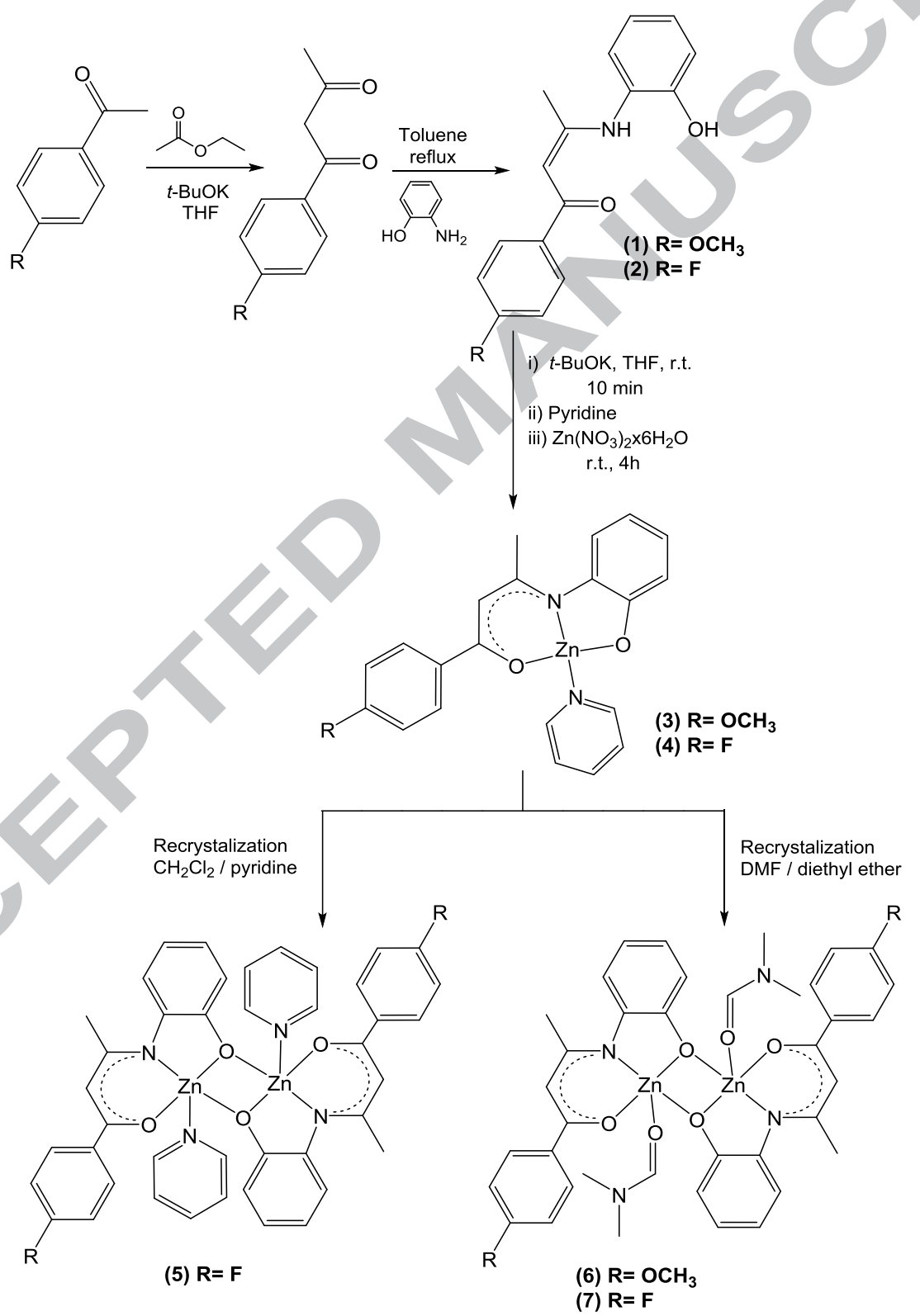

Scheme 1. Synthesis of compounds 1-7 
Recrystallization of 4 from a $\mathrm{CH}_{2} \mathrm{Cl}_{2}$ /pyridine mixture leads to the isolation of the doubly phenoxide-bridged dimeric specie $\mathbf{5}$ with the pyridine ligand occupying the fifth coordination site at the $\mathrm{Zn}(\mathrm{II})$ metal center (Scheme 1). Similarly, recrystallization of $\mathbf{3}$ and $\mathbf{4}$ from vapor diffusion of diethyl ether into respective DMF solutions affords isostructural binuclear complexes 6 and 7, respectively, though with a DMF molecule instead of pyridine as the fifth $\mathrm{Zn}$ (II) coordination ligand (Scheme 1). This ability of $\mathrm{Zn}(\mathrm{II})$ to form binuclear complexes has been reported in previous works $[23,31,32,46,47]$. Only those three binuclear complexes 5-7 were tested as catalysts in the ROP of rac-Lactide depicted in this paper (see Section 3.3).

\subsection{Compound characterization}

Mononuclear complexes $\mathbf{3}$ and $\mathbf{4}$ were characterized by satisfactory elemental analysis, ${ }^{1} \mathrm{H}$ NMR spectroscopy and mass spectrometry as detailed in the experimental section, clearly informing that they correspond to the proposed structures. Fig. 1 compares the ${ }^{1} \mathrm{H}$ NMR spectra of these complexes to those of their respective ligands. Spectra of tridentate ligands $\mathbf{1}$ and $\mathbf{2}$ recorded in deuterated chloroform show all proton peaks. Both compounds have fairly similar spectra, with slight differences in the chemical shifts, due to phenyl ring substitution with $\mathrm{MeO}$ - for $\mathbf{1}$ and F- for $\mathbf{2}$. The acceptor character of the fluorine substituent causes an downfield shift of the proton signals ( $\mathrm{d}$ and e, Fig. 1). Ligand 2 has greater aromatic proton signal multiplicity: the triplet observed at $6.86 \mathrm{ppm}$ for compound 1 (g, Fig. 1), appears again for ligand 2 at $6.89 \mathrm{ppm}$. The signal here is a triplet of doublet, confirming $\mathrm{F}$ nucleus coupling with phenyl ring proton nuclei. In spectra of both $\mathbf{1}$ and $\mathbf{2}$, an acidic $\mathrm{N}-\mathrm{H}$ proton is observed above $12 \mathrm{ppm}$, likely due to its intramolecular hydrogen bond with the carbonyl oxygen.

Fig. 1 shows the ${ }^{1} \mathrm{H}$ NMR spectra of $\mathrm{Zn}(\mathrm{II})$ complexes 3 and $\mathbf{4}$.Unlike their respective ligands, these were insoluble in deuterated chloroform, so measurements were made in lower concentrations of deuterated DMSO solutions. Here, all protons were also assigned, largely similar, though with aromatic proton displacement differences. Three proton signals corresponding to coordinated pyridine were observed in both compounds (j, k, and 1, Fig. 1). Finally, the absence of acidic N-H protons in both complexes confirms ligand coordination to the metal center through the amino nitrogen atom. The ${ }^{1} \mathrm{H}$ NMR signals did not present large differences in chemical displacement, with the only exception in the methyl proton peaks (b, Fig. 1).From complexes to corresponding ligands, these protons are downfield shifted, passing from 1.67 and 1.77 ppm for $\mathbf{1}$ and $\mathbf{2}$, to 2.32 
and 2.33 ppm for $\mathbf{3}$ and $\mathbf{4}$, respectively. Those chemical shift differences bear testimony to the coordination of the ligands to the $\mathrm{Zn}$ (II) metal ion and formation of rigid structures.

(1)
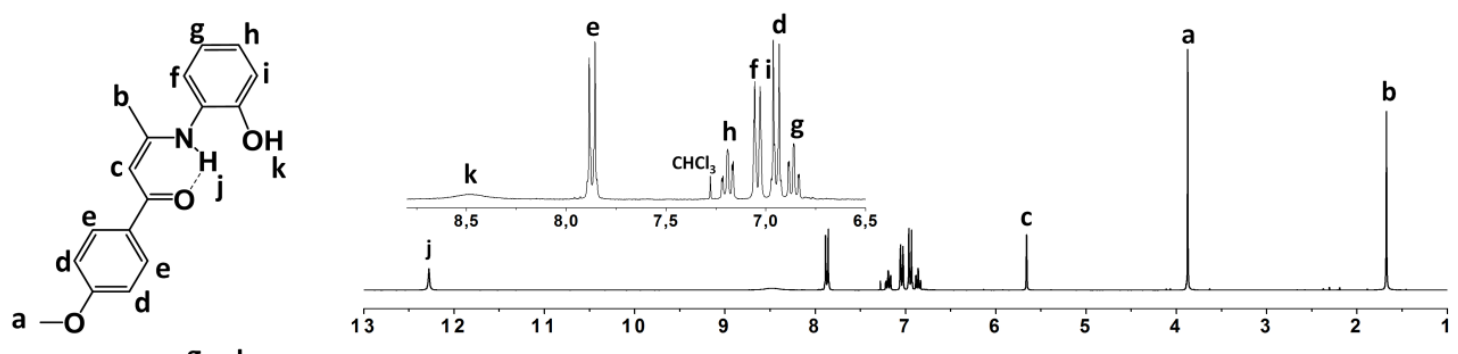

(2)
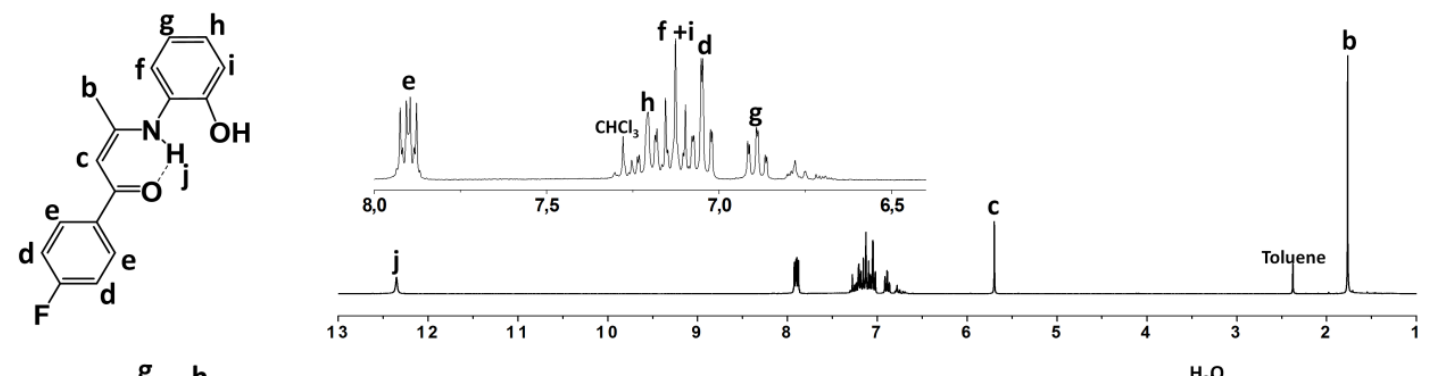

(3)
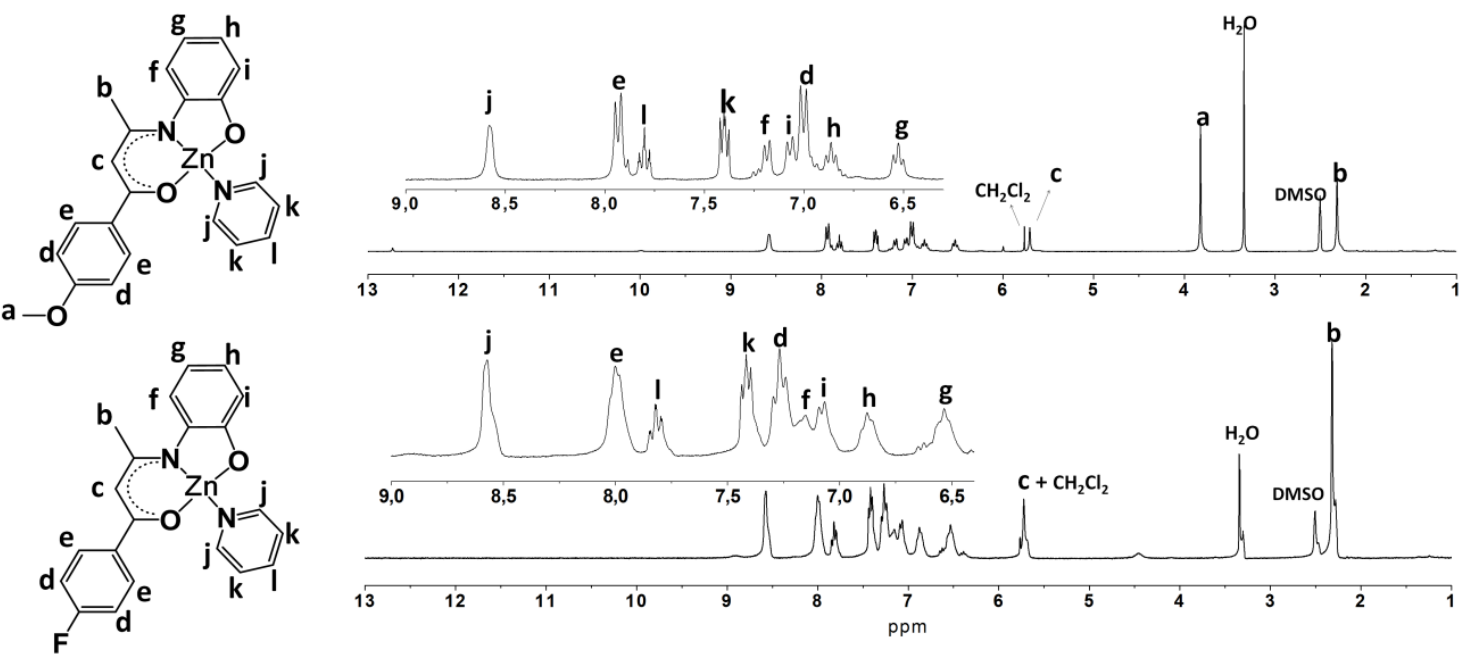

Fig. ${ }^{1} \mathrm{H}$ NMR spectra of $\mathbf{1}$ and $\mathbf{2}$ obtained in $\mathrm{CDCl}_{3}$; and of $\mathbf{3}$ and $\mathbf{4}$ recorded in DMSO-d 6 .

\subsection{X-ray crystallography}

The molecular structure of 5 is displayed in Fig. 2 while those of $\mathbf{6}$ and $\mathbf{7}$ are presented in Fig. 3.

Selected bond lengths and angles of the first $\mathrm{Zn}$ (II) coordination sphere of 5-7 are given in

Table 2. compounds 5, $\mathbf{6}$ and $\mathbf{7}$ crystallize in the orthorhombic, triclinic and monoclinic crystal 
systems in the centrosymmetric space groups $\mathrm{P} b c a, \mathrm{P} \overline{1}$ and $\mathrm{P} 2_{1} / \mathrm{c}$, respectively. The X-ray crystal structures of 5-7 indicate that the three complexes are doubly phenoxide-bridged dimeric species in which each monomeric unit is composed of a pentacoordinated $\mathrm{Zn}$ (II) metal center through a dianionic O,N,O-tridentate Schiff base ligand, a bridging oxygen atom and either a pyridine (5) or a DMF (6 and 7) molecule. On the other hand, the three dimeric complexes generate the whole molecular structure related by an inversion center $(\overline{1})$, in the middle of the molecule due to their high molecular symmetry. Moreover, all the compounds present a slightly distorted square pyramidal geometry $\left(\tau_{5}=0.07,0.06\right.$ and 0.65 , respectively)[48].

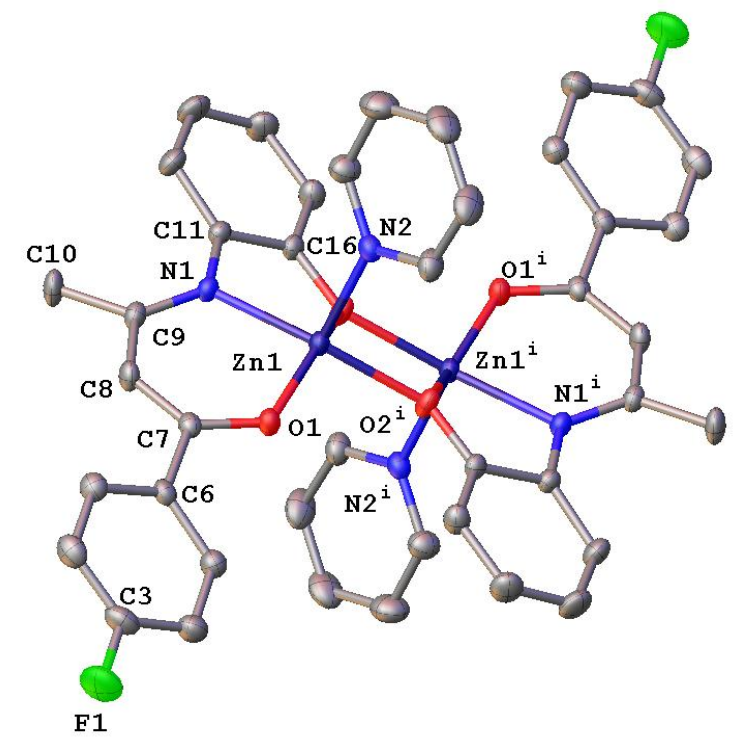

Fig. 2 ORTEP plot of compound 5. Hydrogen atoms are omitted for clarity. Thermal ellipsoids are drawn with $30 \%$ probability. 

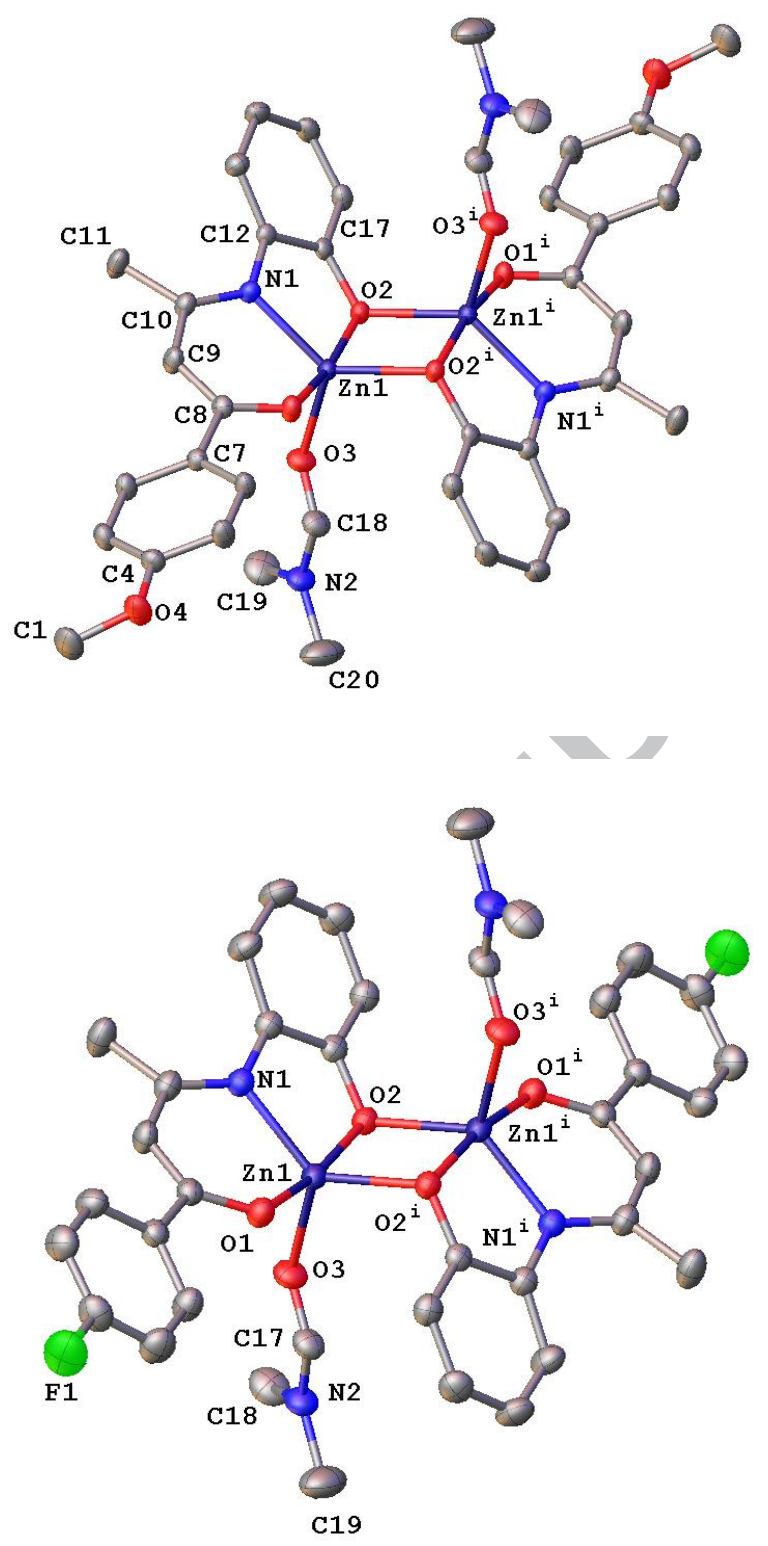

Fig. 3 ORTEP plots of compounds 6 (above) and 7 (below). Hydrogen atoms are omitted for clarity. Thermal ellipsoids are drawn with $30 \%$ of probability $(i=\bar{X}, \bar{Y}, \bar{Z})$.

All the bond distances and angles (Table 2) are in agreement with those of previously reported zinc(II) complexes with similar features [49,50] and the formation of five- and six-membered metallacycles shows distortions similar to that observed for known structurally characterized Schiff base complexes [37,38,51]. Nevertheless, the metrical parameters measured in the two fused heterometallacycles are indicative of a $\pi$ delocalization over the entire system. 
It is also important to highlight that the distances between apical ligand (Py for compound $\mathbf{5}$ and, DMF for compound 6 and 7), present a bond distance slightly larger than other similar compounds $[49,50]$. This feature could be responsible for their catalytic response in ring opening polymerization of rac-lactide, according to its catalytic mechanism [8,25]. Between the three complexes, there are not major differences in their structural parameters (Table 2). However, the bond distances in the apical ligand in each compound, allow to infer about the catalytic response between compounds 5 - 7, due to DMF as ligand, is a weak ligand than Py. This could explain the greater reactivity that compound 7 presented under mild polymerization conditions, but at the same time, a lower control in the polydispersity of PLA. These results are discussed in more detail in section 3.4.

Table 2. Selected Bond distance $(\AA)$ and angles $\left(^{\circ}\right)$ of the $\mathrm{Zn}(\mathrm{II})$ coordination core for compounds 5-7.

\begin{tabular}{|c|c|c|c|}
\hline Compound & 5 & $\bar{\Delta}$ & 7 \\
\hline \multicolumn{4}{|c|}{ Bond distances } \\
\hline $\mathrm{Zn}(1)-\mathrm{O}(1)$ & $1.963(2)$ & $2.004(12)^{\mathrm{b}}$ & $1.999(2)$ \\
\hline $\mathrm{Zn}(1)-\mathrm{O}(2)$ & $2.090(2) / 2.030(2)^{\mathrm{a}}$ & $2.010(11) / 2.124(11)^{b}$ & $2.027(2) / 2.123(14)^{\mathrm{c}}$ \\
\hline $\mathrm{Zn}(1)-\mathrm{N}(1)$ & $2.060(2)$ & $2.024(13)^{\mathrm{b}}$ & $2.013(19)^{\mathrm{c}}$ \\
\hline $\mathrm{Zn}(1)-\mathrm{N}(2)$ & $2.095(2)$ & --- & --- \\
\hline $\mathrm{Zn}(1)-\mathrm{O}(3)$ & & $2.005(12)$ & $2.045(2)$ \\
\hline $\mathrm{Zn}(1)-\mathrm{Zn}(1)$ & $3.250(2)$ & $3.121(3)$ & $3.117(7)$ \\
\hline \multicolumn{4}{|c|}{ Bond angles } \\
\hline $\mathrm{O}(1)-\mathrm{Zn}(1)-\mathrm{L}$ & $105.07(10)$ & $95.15(5)$ & $97.05(6)$ \\
\hline $\mathrm{N}(1)-\mathrm{Zn}(1)-\mathrm{L}$ & $100.33(10)$ & $113.27(6)$ & $117.26(7)$ \\
\hline $\mathrm{O}(2)-\mathrm{Zn}(1)-\mathrm{L}$ & $107.06(10)$ & $92.00(2)$ & $89.93(6)$ \\
\hline $\mathrm{N}(1)-\mathrm{Zn}(1)-\mathrm{O}(2)$ & $78.36(9)$ & $80.08(5)$ & $79.86(6)$ \\
\hline $\mathrm{O}(1)-\mathrm{Zn}(1)-\mathrm{N}(1)$ & $94.52(9)$ & $92.49(5)$ & $92.42(6)$ \\
\hline $\mathrm{O}(1)-\mathrm{Zn}(1)-\mathrm{O}(2)$ & $147.84(10)$ & $171.28(5)$ & $171.39(5)$ \\
\hline $\mathrm{Zn}(1)-\mathrm{O}(2)-\mathrm{Zn}(1)$ & 104.13(9) & $98.00(5)$ & $97.78(8)$ \\
\hline
\end{tabular}

$\mathrm{L}: 5=\mathrm{N}(2) ; 6$ and $7=\mathrm{O}(3)$

${ }^{a} \bar{X}, 1-Y, \bar{Z} ;{ }^{b} \bar{X}, 2-Y, 1-Z ;{ }^{c} 1-X, 1-Y, 1-Z$

\subsection{Reactivity studies of complexes 5-7 in ROP of rac-lactide}

One of the main objectives of this work was to study the catalytic activity of these three complexes 5-7 in ring opening polymerization to obtain PLA. Table 3 shows the polymerization tests performed with the three synthesized binuclear complexes. In short, bulk polymerizations in a melted reaction mixture of monomer rac-LA at $130^{\circ} \mathrm{C}$ for $4-18$ hours and different concentration ratios of monomer and catalyst were studied. Additionally, benzyl alcohol has been incorporated as 
a cocatalyst in some tests, since there are previous reports indicating that different alcohols in low concentration improve the catalytic activity of some complexes [29]. Table 3 also shows the influence of these polymerization variables on the degree of conversion and the molecular weight of the PLA obtained. Fig. 4 shows an example of how ${ }^{1} \mathrm{H}$ NMR characterization allows calculating the degree of conversion through clear differences in monomer and polymer proton signals. Such signals can be individually integrated, giving rise to the composition of the reaction mixture. Furthermore, ${ }^{1} \mathrm{H}$ NMR approximates PLA molecular weight through PLA polymer chain terminal group proton signals (e and g, Fig. 4). Considering the contribution of their areas in relation to the rest of the protons in the spectrum, the number of repetitive monomeric units was calculated, reporting approximate chain length averages $\left(\mathrm{M}_{\mathrm{n}}\right)$. Synthesized PLA samples were also characterized by GPC, which, in addition to the average molecular weight, gives chain size distribution by calculating the polydispersity index (Table 3 ).

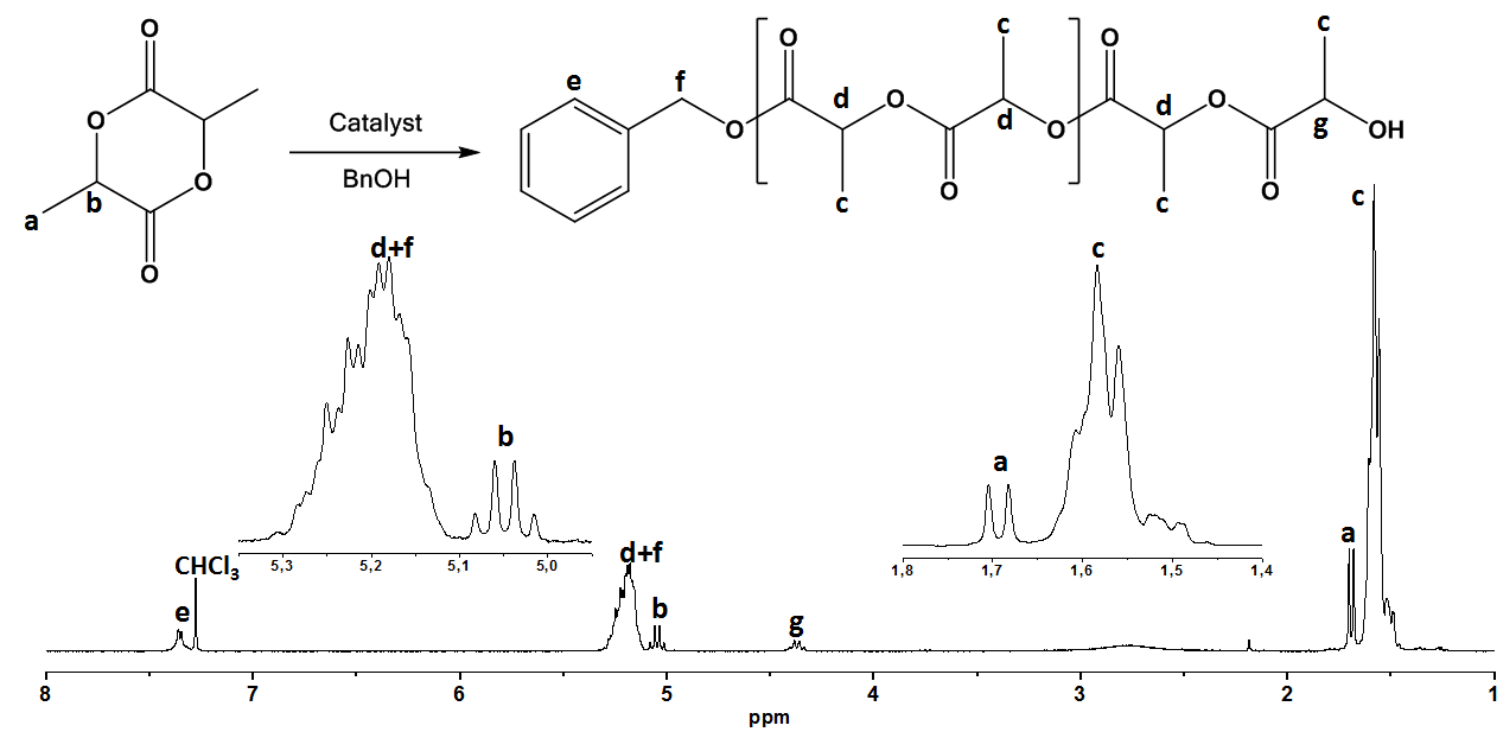

Fig. 4 Example of ${ }^{1} \mathrm{H}$ NMR spectrum of PLA with $87 \%$ conversion, obtained with complex 7 as catalyst and $\mathrm{BnOH}$ as cocatalyst (Table 3, Entry 12). 
Table 3. ROP of rac-lactides catalyzed by complexes $\mathbf{5}, \mathbf{6}$, and $\mathbf{7}$.

\begin{tabular}{|c|c|c|c|c|c|c|c|}
\hline Entry & Complex & $\begin{array}{c}{[r a c-\mathbf{L A}} \\
]:[\mathrm{Zn}]:[\mathbf{B n O H}]\end{array}$ & $\begin{array}{c}\text { Time } \\
\text { (h) }\end{array}$ & $\begin{array}{c}\text { Conv. }^{a} \\
(\%)\end{array}$ & $\begin{array}{c}\mathrm{Mn}_{\mathrm{n}}^{\mathrm{b}} \\
\left(\mathrm{kg} \mathrm{mol}^{-1}\right)\end{array}$ & $\begin{array}{c}\mathrm{M}_{\mathrm{n}}^{\mathrm{c}} \\
\left(\mathrm{kg} \mathrm{mol}_{\mathbf{1}}^{-}\right.\end{array}$ & $\mathbf{M}_{\mathrm{w}} / \mathbf{M}_{\mathbf{n}}^{\mathrm{c}}$ \\
\hline 1 & 5 & $400: 1: 0$ & 4 & 69 & 2.2 & 1.7 & 1.30 \\
\hline 2 & 5 & $400: 1: 20$ & 4 & 97 & 2.3 & 1.7 & 1.33 \\
\hline 3 & 5 & 400:1:0 & 18 & 97 & 3.5 & 4.4 & 1.38 \\
\hline 4 & 5 & 800:1:0 & 18 & 95 & 4.9 & 6.0 & 1.55 \\
\hline 5 & 6 & 400:1:0 & 4 & 68 & 2.0 & 1.5 & 1.17 \\
\hline 6 & 6 & $400: 1: 20$ & 4 & 98 & 4.1 & 5.8 & 1.60 \\
\hline 7 & 6 & 400:1:0 & 18 & 98 & 4.0 & 4.1 & 1.76 \\
\hline 8 & 6 & 800:1:0 & 18 & 92 & 8.5 & 13.3 & 1.34 \\
\hline 9 & 7 & 400:1:0 & 4 & 78 & 2.5 & 1.8 & 1.28 \\
\hline 10 & 7 & $400: 1: 20$ & 4 & 97 & 2.5 & 1.9 & 1.34 \\
\hline 11 & 7 & $800: 1: 0$ & 4 & 67 & 3.1 & 3.0 & 1.30 \\
\hline 12 & 7 & $800: 1: 20$ & 4 & 87 & 3.6 & 4.0 & 1.52 \\
\hline 13 & 7 & 400:1:0 & 18 & 97 & 4.8 & 5.9 & 1.90 \\
\hline 14 & 7 & $400: 1: 20$ & 18 & 98 & 2.6 & 2.4 & 1.54 \\
\hline 15 & 7 & 800:1:0 & 18 & 95 & 3.6 & 4.9 & 1.59 \\
\hline 16 & 7 & $800: 1: 20$ & 18 & 98 & 3.6 & 4.4 & 1.60 \\
\hline
\end{tabular}

${ }^{a}$ Conversion percentage determined by ${ }^{1} \mathrm{H}$ NMR; ${ }^{b}$ Average molecular weight determined by ${ }^{1} \mathrm{H}$ NMR; ${ }^{c}$ Average molecular weight and polydispersity index determined by GPC calibrated versus polystyrene standards and corrected by a factor of 0.58 according to literature recommendations [52].

Table 3 shows some general trends of the catalytic behavior of complexes 5-7. After 4 hours of reaction, no complex is able to generate the highest possible degree of conversion; after 18 hours, however, or with $\mathrm{BnOH}$ as co-catalyst, all conversions reach high values (>90\%). Of the three catalysts studied, complex 7 achieves $78 \%$ conversion in 4 hours of reaction, making it the fastest catalyst under these conditions (Entries 1, 5, and 9).Reaction times of 18 hours provide conversions of around $98 \%$ for all catalysts, similar to results obtained with benzyl alcohol (Entries 2, 6, and 10). On the other hand, reducing catalyst concentration by half ([rac-LA]:[Zn] $=800: 1)$ negatively affects conversion rates, independent of co-catalyst (entries 11 and 12). This is quite expected, due to the lower concentration of active centers to initiate polymerization.If the same concentration of catalyst is allowed to react for a longer time, however, conversions can be equally high as in cases where the concentration of catalyst is higher (entries 4, 8, and 15). Decreasing the catalyst 
concentration may affect PLA molecular weight. Indeed, initial catalyst concentrations generally generated relatively low molecular weights, ranging from 1.7 to $4.4 \mathrm{~kg} \mathrm{~mol}^{-1}$ (400:1). Thus a decrease in active polymerization sites should generate longer PLA chains if polymerization is stable over time.

To discuss the influence of catalysts and reaction conditions on the molecular weight of PLA, it is necessary to consider some differences of the two methods by which the average molecular weight $\left(\mathrm{M}_{\mathrm{n}}\right)$ value has been calculated. Although GPC is one of the most widely used, and considered the most suitable method for the determination of $M_{n}$ of polymers, the ${ }^{1} \mathrm{H}$ NMR method also provides a good approximation of this value. Table 3 shows how the ${ }^{1} \mathrm{H}$ NMR method approximates more closely to GPC results when molecular weight values are lower. In such cases terminal group proton contribution is greater, accounting for the majority of integrated signals. In addition, methodology results are similar for low polydispersity samples because ${ }^{1} \mathrm{H}$ NMR calculations assume equal chain size. In some cases, the methods differ by less than $10 \%$ (entries 11,12,14); in others, more considerably (30\%, entry 8). Nevertheless, increasing or decreasing trends for PLA molecular weight are of the same respect to the polymerization conditions variation. Thus both methodologies provide information for catalyst behavior and reaction condition effects on $\mathrm{Mn}$.

The results presented in Table 3 show that $M_{n}$ increases when the concentration of catalyst decreases. Catalyst 6 reaches $13.3 \mathrm{~kg} \mathrm{~mol}^{-1}$ with only a slight increase in polydispersity. This is remarkable since other $\mathrm{M}_{\mathrm{n}}$ increases are accompanied by considerable increases in polydispersity. Next, as time and conversion rate, PLA chain length also tends to increase, though with different $M_{n}$ and polydispersity effects for each complex. For example, decreased concentrations of catalyst $\mathbf{5}$ increase chain length by up to $200 \%$ (entry 4), without seriously affecting polydispersity. This implies heterogeneous catalyst reactivity: over an extended period of 18 hours, not all active centers are equally effective, therefore generating chains of different length. On the other hand, and unique to catalyst $\mathbf{5}, \mathrm{M}_{\mathrm{n}}$ can be slightly increased by increasing time without decreasing concentration, while mostly maintaining polydispersity (entry 3 ). In this case, a higher catalyst concentration favors more stable polymerization. The latter behavior could be attributed to the presence of pyridine as an auxiliary ligand in catalyst $\mathbf{5}$. Finally, although $\mathrm{BnOH}$ as a co-catalyst allows better conversions, the effect on $\mathrm{M}_{\mathrm{n}}$ is negative. In the only case where there is a considerable increase in $\mathrm{M}_{\mathrm{n}}$, polydispersity is highly increased. In general, it is advisable to reduce concentration of the three catalysts and extend reaction times.

The three catalysts behave similarly to changes in reaction conditions, e.g., $\mathrm{BnOH}$ presence or different concentrations. That said, differences may be attributable to structural modifications, like 
the auxiliary ligand (DMF vs. pyridine) or the nature of the substituents (F vs. MeO). For example, catalysts 5 and 7, which have fluoride in their structure, generate better conversions at shorter reaction times, but lower PLA molecular weights, implying that the acceptor effect of fluoride favors more reactive, less-controlled polymerization. Less reactive catalyst 6 bearing the MeOsubstituent, achieves higher molecular weights with the advantage of maintaining polydispersity. Finally, the effect of the auxiliary ligand under identical conditions for complexes $\mathbf{5}$ and $\mathbf{7}$ (entries 3 and 15) shows very little difference in conversion percentage; that said,at higher $M_{n}$ values, the DMF catalyst presents an important increase in polydispersity, which does not occur in the case of pyridine (catalyst $\mathbf{5}$ ).

\section{Conclusions}

$\mathrm{Zn}$ (II) binuclear complexes 5, 6, and $\mathbf{7}$ synthesized via dimerization of their fully characterized mononuclear precursors $\mathbf{3}$ and $\mathbf{4}$ during recrystallization were found to be stable compounds under environmental conditions, capable of being used as catalysts in the rac-LA polymerization reactions. They are similar in regards to $\mathrm{ROP}$, with high sensitivity toward the presence of $\mathrm{BnOH}$ as a co-catalyst or higher conversion rates over longer periods of time. On the other hand, PLA with different characteristics can be synthesized by controlling polymerization conditions (time and catalyst concentration) in the absence of $\mathrm{BnOH}$. Here, the catalytic behavior is attributed to structural differences. Complexes with a fluoride substituent were slightly more reactive but had less control over average molecular weight than the catalyst bearing the donor methoxy group. The inclusion of pyridine instead of DMF as an auxiliary fifth coordination ligand generates better control of PLA polydispersity. Finally, the MeO-substituted catalyst generated the highest $\mathrm{M}_{\mathrm{n}}$ PLA when used in low concentrations, though with a reaction time of $18 \mathrm{~h}$ and a conversion rate slightly lower than other catalysts under the same polymerization conditions.

\section{Acknowledgements}

The authors thank F. Lambert (CRMPO, Rennes) for helpful assistance with MS measurements. Financial support from FONDECYT Postdoctoral project 3160673 (D.M.G.), FONDEQUIP (EQM130154), the Vicerrectoría de Investigación y Estudios Avanzados, Pontificia Universidad Católica de Valparaíso, Chile (D.M.G. and C.M.), the CNRS and the Universite de Rennes 1 is gratefully acknowledged. I.B. and J.C. thank FONDEQUIP (EQM 130021) and financial support 
from Universidad de Antofagasta for the access to Cambridge Structural Database (CSD), and J.C. thanks de Universidad de Antofagasta for the Postdoctoral Fellowship.

\section{Appendix A: supplementary information.}

CCDC 1862423 (for 5), 1863233 (for 6) and 1862424 (for 7) contain the supplementary crystallographic data for this paper. These data can be obtained free of charge from the Cambridge Crystallographic Data Centre via www.ccdc.cam.as.uk/data_request/cif

\section{References}

[1] B. Jeong, Y.H. Bae, D.S. Lee, S.W. Kim, Nature 388 (1997) 860-862.

[2] T. Maharana, B. Mohanty, Y.S. Negi, Prog. Polym. Sci. 34 (2009) 99-124.

[3] J. Rydz, W. Sikorska, M. Kyulavska, D. Christova, Int. J. Mol. Sci. 16 (2015) 564-596.

[4] Y. Wang, W. Zhao, D. Liu, S. Li, X. Liu, D. Cui, X. Chen, Organometallics 31 (2012) 4182-4190.

[5] S. Farah, D.G. Anderson, R. Langer, Adv. Drug Deliv. Rev. 107 (2016) 367-392.

[6] G. Schwach, J. Coudane, R. Engel, M. Vert, J. Polym. Sci. Part A Polym. Chem. 35 (1997) 3431-3440.

[7] X. Pang, X. Zhuang, Z. Tang, X. Chen, Biotechnol. J. 5 (2010) 1125-1136.

[8] Y. Sarazin, V. Poirier, T. Roisnel, J.-F. Carpentier, Eur. J. Inorg. Chem. (2010) 3423-3428.

[9] S. Slomkowski, S. Penczek, A. Duda, Polym. Adv. Technol. 25 (2014) 436-447.

[10] O. Dechy-cabaret, B. Martin-vaca, D. Bourissou, Chem. Rev. 104 (2004) 6147-6176.

[11] A. Kowalski, J. Libiszowski, T. Biela, M. Cypryk, A. Duda, S. Penczek, Macromolecules 38 (2005) 8170-8176.

[12] Y. Sarazin, J.-F. Carpentier, Chem. Rev. 115 (2015) 3564-3614.

[13] X. Pang, R. Duan, X. Li, X. Chen, Polym. Chem. 5 (2014) 3894-3900.

[14] W. Zhang, Y. Wang, L. Wang, C. Redshaw, W.H. Sun, J. Organomet. Chem. 750 (2014) $65-73$.

[15] M. Bouyahyi, T. Roisnel, J.-F. Carpentier, Organometallics 29 (2010) 491-500.

[16] Z. Zhong, P.J. Dijkstra, J. Feijen, J. Am. Chem. Soc. 125 (2003) 11291-11298.

[17] K. Majerska, A. Duda, J. Am. Chem. Soc. 126 (2004) 1026-1027.

[18] C.M. Thomas, Chem. Soc. Rev. 39 (2010) 165-173.

[19] H. Du, A.H. Velders, P.J. Dijkstra, Z. Zhong, X. Chen, J. Feijen, Macromolecules 42 (2009) 1058-1066. 
[20] Z. Dai, Y. Sun, J. Xiong, X. Pan, N. Tang, J. Wu, Catal. Sci. Technol. 6 (2016) 515-520.

[21] H.-Y. Chen, J. Zhang, C.-C. Lin, J.H. Reibenspies, S.A. Miller, Green Chem. 9 (2007) $1038-1040$.

[22] W. Xie, D. Chen, X. Fan, L.I. Jun, P.G. Wang, H.N. Cheng, R.G. Nickol, J. Polym. Sci. Part A Polym. Chem. 37 (1999) 3486-3491.

[23] C.A. Wheaton, P.G. Hayes, B.J. Ireland, Dalton Trans. (2009) 4832-4846.

[24] W. Hung, C. Lin, Inorg. Chem. 48 (2009) 728-734.

[25] Y. Sarazin, B. Liu, T. Roisnel, L. Maron, J.-F. Carpentier, J. Am. Chem. Soc. 133 (2011) 9069-9087.

[26] D. Chakraborty, D. Mandal, V. Ramkumar, V. Subramanian, J. Vijaya Sundar, Polymer (Guildf). 56 (2015) 157-170.

[27] K.S. Kwon, S. Nayab, H.I. Lee, J.H. Jeong, Polyhedron 126 (2017) 127-133.

[28] K.S. Kwon, S. Nayab, J.H. Jeong, Polyhedron 130 (2017) 23-29.

[29] D. Jędrzkiewicz, G. Adamus, M. Kwiecień, Ł. John, J. Ejfler, Inorg. Chem. 56 (2017) 13491365.

[30] X.X. Zheng, Z.X. Wang, J. Organomet. Chem. 823 (2016) 14-22.

[31] M. Honrado, A. Otero, J. Fernández-Baeza, L.F. Sánchez-Barba, A. Garcés, A. LaraSánchez, A.M. Rodríguez, Eur. J. Inorg. Chem. (2016) 2562-2572.

[32] H.Y. Chen, H.Y. Tang, C.C. Lin, Macromolecules 39 (2006) 3745-3752.

[33] S. Abbina, G. Du, ACS Macro Lett. 3 (2014) 689-692.

[34] S.O. Ojwach, T.T. Okemwa, N.W. Attandoh, B. Omondi, Dalton Trans. 42 (2013) 1073510745.

[35] N. Novoa, J.P. Soto, R. Henríquez, C. Manzur, D. Carrillo, J.-R. Hamon, J. Inorg. Organomet. Polym. Mater. 23 (2013) 1247-1254.

[36] A. Trujillo, M. Fuentealba, D. Carrillo, C. Manzur, I. Ledoux-Rak, J.-R. Hamon, J.-Y. Saillard, Inorg. Chem. 49 (2010) 2750-2764.

[37] N. Novoa, F. Justaud, P. Hamon, T. Roisnel, O. Cador, B. Le Guennic, C. Manzur, D. Carrillo, J.-R. Hamon, Polyhedron 86 (2015) 81-88.

[38] N. Novoa, T. Roisnel, P. Hamon, S. Kahlal, C. Manzur, H.M. Ngo, I. Ledoux-Rak, J.-Y. Saillard, D. Carrillo, J.-R. Hamon, Dalton Trans. 44 (2015) 18019-18037.

[39] J. Cisterna, V. Artigas, M. Fuentealba, P. Hamon, C. Manzur, V. Dorcet, J.-R. Hamon, D. Carrillo, Inorg. Chim. Acta 462 (2017) 266-280.

[40] W.L.F. Armarego, C.L.L. Chai, Purification of Organic Chemicals, 5th ed., ButterworthHeinemann, Elsevier Inc., Amsterdam, The Netherlands, 2003. 
[41] V.V. Popic, S.M. Korneev, V.A. Nikolaev, I.K. Korobitsyna, Synthesis (Stuttg). (1991) 195-198.

[42] X. Shen, A.J. Borah, X. Cao, W. Pan, G. Yan, X. Wu, Tetrahedron Lett. 56 (2015) 64846487.

[43] Bruker APEX3, SAINT and SADABS, Bruker AXS Inc., Madison, Wisconsin, USA (2016).

[44] G.M. Sheldrick, Acta Crystallogr. Sect. C Struct. Chem. 71 (2015) 3-8.

[45] O.V. Dolomanov, L.J. Bourhis, R.J. Gildea, J.A.K. Howard, H. Puschmann, J. Appl. Crystallogr. 42 (2009) 339-341.

[46] H. Wen-Chou, H. Yong, L. Chu-Chieh, J. Polym. Sci. Part A Polym. Chem. 46 (2008) 6466-6476.

[47] A. Thevenon, C. Romain, M.S. Bennington, A.J.P. White, H.J. Davidson, S. Brooker, C.K. Williams, Angew. Chem. Int. Ed. 55 (2016) 8680-8685.

[48] A.W. Addison, T.N. Rao, J. Reedijk, J. van Rijn, G.C. Verschoor, J. Chem. Soc. Dalton Trans. (1984) 1349-1356.

[49] J. Peng, H.-J. Yang, Z. Wei, C.-Y. Guo, RSC Adv. 5 (2015) 53063-53072.

[50] C. Di Iulio, M. Middleton, G. Kociok-Köhn, M.D. Jones, A.L. Johnson, Eur. J. Inorg. Chem. (2013) 1541-1554.

[51] N. Novoa, T. Roisnel, V. Dorcet, O. Cador, C. Manzur, D. Carrillo, J.-R. Hamon, New J. Chem. 40 (2016) 5920-5929.

[52] J. Baran, A. Duda, A. Kowalski, R. Szymanski, S. Penczek, Macromol. Rapid Commun. 18 (1997) 325-333. 

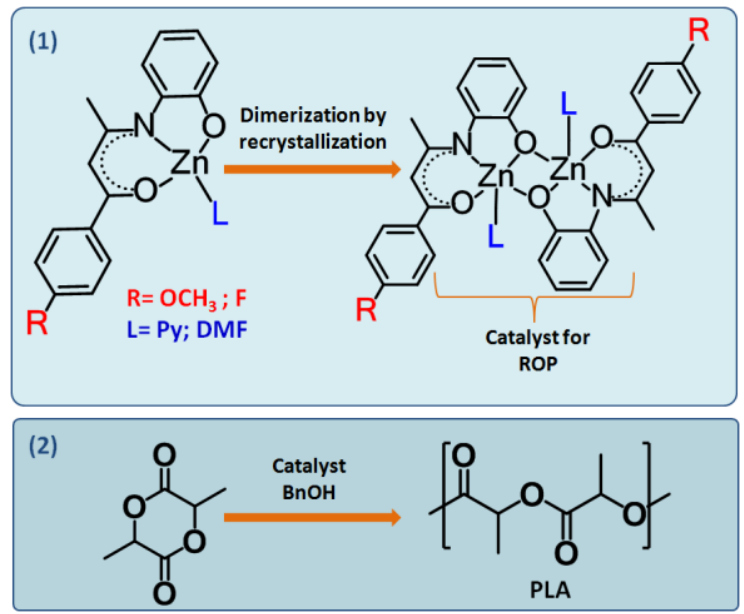

Binuclear (II) zinc complexes were obtained from dimerization of their mononuclear precursors with the aim of studying the catalytic activity of these compounds in the ring-opening polymerization of rac-lactide, considering the influence of its structural features on the conversion percentage, molecular weight average and polydispersity of the obtained PLA. 